\title{
On the Development Path of Rural Leisure Tourism Industry under the Background of Rural Revitalization Strategy
}

\author{
Fang Zhou \\ Xi’an Peihua University, Xi’an Shaanxi, 710125
}

Keywords: Rural revitalization strategy; Rural leisure tourism; Rural tourism industry

\begin{abstract}
Leisure tourism industry is based on agriculture, rural areas and farmers, and integrates the new industrial pattern of agriculture, rural areas and farmers. In recent years, leisure agriculture and rural tourism have become an important channel for rural development and agricultural transformation, has become an important carrier to meet the leisure consumption needs of urban and rural residents. The report of the Nineteenth National Congress of the Communist Party of China puts forward the strategy of rural rejuvenation in our country, and puts forward new requirements and guidance for the development of rural areas. The combination of leisure agriculture and rural tourism is the main grasp of carrying out the strategy of rural revitalization.
\end{abstract}

\section{Introduction}

Document No. 1 of 2017 pointed out that we should vigorously develop the rural leisure tourism industry, and put forward for the first time the thinking of industrialization to develop the rural tourism industry.Through horizontal extension of the tourism industry chain, vertical integration of industrial development to promote rural tourism industry upgrading.The document emphasizes the deep integration of agriculture, forestry and tourism, education, culture and health care industries through the modes of "tourism+ " and "ecology+ ", and provides support from various aspects such as mode, industry, organization, capital and regulation for the development of rural leisure tourism industry. Document No. 1 clearly emphasizes the use of industrial thinking to develop rural tourism. We should recognize that the development space of rural leisure tourism in the new background will be more extensive, and the dimensions of the development of rural leisure tourism.Rural tourism is no longer just a simple farming or farming picking, but to capture more potential resources, including mountains, fields, sunshine, air, houses and farmers, so as to expand the potential value and added value of rural tourism.Such as taking advantage of environmental differences and ecological conditions between rural and urban areas to develop "rural + health care" rural sojourn vacation; The use of rural agricultural resources for urban families, especially for urban children's scarcity, curious development of "rural + parent-child" rural complex and so on.New trend has come, we need to use more open field of vision and a more open attitude to meet rural resources and the development of rural leisure tourism space under the new background, to make the rural tourism from tourism products to rural leisure tourism industrial upgrading, make rural agricultural industrial chain and value chain is expanded and continue, also to solve the problem of rural tourism supply side structural seek breakthrough.

\section{The importance of the development of rural leisure tourism industry under the background of Rural Revitalization Strategy}

In the rural revitalization strategy, the combination of leisure agriculture and rural tourism industry needs to give full play to the initiative, which also reflects the positioning of leisure agriculture and rural tourism industry in the strategic grand pattern. In the new era, from the connotation of the people's need for a better life, the leisure agriculture and rural tourism industries are required to place their own consciousness on the overall situation of rural revitalization and not be in the passive position of accepting the urban consumption demand, no matter from the rural needs or the urban ones. 
The industrial characteristics of the integration of production, life and ecological functions of leisure agriculture and rural tourism industry determine it has the "gene" of rural revitalization naturally. Leisure agriculture and rural tourism industry can not only convert agricultural rural ecological advantage into economic advantage, but also to the rural sentiment and to gather the resources factor, is conducive to the improvement of rural living environment, promote rural harmonious coexistence of human and nature, and is conducive to form a pattern of resource saving and environment friendly country space, industrial structure, mode of production and way of life. According to the general requirements of industrial prosperity, ecological livability, rural civilization, effective governance and rich life, leisure agriculture and rural tourism industry are the best supporting points for the rural revitalization strategy.

\section{The current situation of Rural Leisure Tourism Industry}

Our country's leisure agriculture and rural tourism industry have gradually expanded from the primary form of "appreciating flowers and fruits" and "eating more chickens" to many functions, such as agricultural experience, ecological protection, cultural heritage, etc. after years of development, constantly adapting to the needs of urban people into nature, understand agriculture, experience the interests of agriculture, science education. Under the background of urbanization, which attracts urban resources to rural areas, leisure agriculture and rural tourism industry attract the attention of the industry. "One Three Interaction" travels to help agriculture become a hot word for agricultural rural development, and become a farmer's income increase. Agricultural efficiency, an important breakthrough point for rural prosperity. According to incomplete statistics, China's leisure agriculture and rural tourism has reached 330,000 in 2017, an increase of more than 30,000 over the previous year, with operating income of nearly 620 billion Yuan, the whole industry showing a "blowout" growth trend.

\section{Problems in the Development of Rural Leisure Tourism Industry under the background of Rural Revitalization Strategy}

Document No. 1 of 2017 pointed out that focus on the structural Reform on the supply side of Agriculture. With regard to rural tourism, document No. 1 for the first time proposes to vigorously develop the rural leisure tourism industry from the perspective of the macro industrial chain. It can be seen that rural tourism has been promoted to the pattern of large industries. This is a new situation for the development of rural tourism. While rural tourism is developing in full swing, there are many low quality products, few high quality products and uneven distribution of product types,. Specifically, the current rural tourism products in most regions have some problems, such as low quality, lack of characteristics and rough product types, and the low quality products are too much, and the market supply is serious excess. The rural tourism products with relatively high quality such as Mogan Mountain and Dali are relatively few in quantity, concentrated in distribution and decentralized in management.

The construction of rural leisure tourism industry needs to find more development space on the basis of clear development problems. As a new industrial form and consumption form, leisure agriculture and rural tourism still have some problems in the process of rapid development, such as insufficient ideological preparation, lagging infrastructure and improving service quality. More extensive, and explosive growth of the market demand is not compatible. The more fierce the market, the higher the enthusiasm, the more leisure agriculture and rural tourism industry from the long-term development, speed up industrial upgrading, orderly development, healthy development, sustainable development, real farmer labor and life, rural style and appearance, agricultural characteristics of the body. We are trying to make leisure agriculture and rural tourism a new growth pole for farmers to increase employment. 


\section{The existing Mode of the Development of Rural Leisure Tourism Industry}

\subsection{Pastoral agricultural tourism model}

Around "Agriculture, Farmers, Rural Area", the related leisure agriculture and rural tourism, such as pastoral agriculture tour, garden sightseeing tour, agricultural science and technology tour, agricultural experience tour and so on, are carried out. Let the tourists close to nature, enjoy the green landscape of pastoral, but also experience the life of farmers, increase knowledge of modern agricultural production.

\subsection{Leisure vacation tourism mode}

With the development of urbanization, more and more families live in tall buildings in the city. People yearn for the beautiful environment of nature and the fresh air. Based on the superiority of the natural environment, we can build leisure resorts, leisure farms, rural hotels and so on with tourist recreation, vacation, entertainment, catering, fitness and other services.

\subsection{Farmers' courtyard entertainment tourism model}

This is the most common tourism mode at present. Because of its low price, farmers can make use of their own courtyard, food, housing, play, travel, entertainment, shopping and other tourism activities. The main types are agricultural sightseeing, folk dwelling, folk culture, entertainment, food and lodging, participation in farming, etc.

\subsection{Folk customs tourism mode}

The farming culture of the Chinese nation is rich and extensive, the rural folk culture is the crystallization of thousands of years' wisdom of producing and living in rural people, the folk customs and folk traditional skills of the local festivals are also quite cultural connotations. This is the attraction of tourism; we can develop farming culture tourism, folk culture tourism, local culture tourism, national culture tourism and other folk customs tourism.

\subsection{Village and township tourism mode}

Taking the ancient village and town house building and the new countryside pattern as the tourist attraction, develops the sightseeing tour. Such as ancient residence and ancient house tour, ethnic village tourism, ancient town building tour, new village style tour and other village tourism mode.

\subsection{Popular science education tourism model}

With the improvement of material living standard, people's demand for culture increases obviously. The tourism mode of popular science education can improve people's quality of agricultural science and culture, generally set up agricultural sightseeing garden, science and technology ecological park, agricultural product exhibition hall, agricultural expo park or museum, etc. For example, the agricultural science and technology education base, the sightseeing leisure education agriculture garden, the agriculture expo garden and so on, enables the visitor to study in the traveling and traveling in the study.

\subsection{Return to natural tourism mode}

The mode of returning to nature tourism is mainly the return of tourists to nature. Based on this model, forest parks, wetland parks, water parks, open camps, nature reserves and so on can be built. With the unique natural landscape, visitors will be able to feel the enjoyment of nature. 


\section{The Development path of Rural Leisure Tourism Industry under the background of Rural Revitalization Strategy}

\subsection{Construction of Leisure Agriculture Industry Development Model with strong Local characteristics and Agricultural characteristics}

According to the natural conditions and the endowment of agricultural resources, all localities can combine people's consumption need, to increase the depth of the development of leisure agricultural resources, and constantly adjust the industrial layout, to construct a strong local characteristics and agricultural characteristics of leisure agriculture industry development model.

\subsection{Focus on cultivating Local characteristic Brand}

Rural areas play an important role in promoting agricultural function, excavating farming culture, protecting ecological environment, improving service facilities, developing characteristic products and improving service quality. The Ministry of Agriculture has seized on the brand to nurture the cow's nose. According to the idea of combination of points and lines, through optimization and integration, the emphasis is to create the brand system of leisure agriculture and rural tourism. The national leisure agriculture and rural tourism demonstration counties (cities and districts) should be established, the beautiful leisure rural areas in China should be promoted, and the leisure agriculture and rural tourism scenic spots should be promoted online. Efforts should be made to cultivate important agricultural cultural heritage and encourage the cultivation of local brands with their own characteristics.

\subsection{To Innovate rural leisure tourism development}

It is necessary to promote the transformation of agricultural areas into scenic spots, improve facilities, purify and beautify, distribute ideas, promote scenic spots of agricultural resources, let farmers live in scenic areas and become rich in scenic spots, while ensuring that agricultural functions remain unchanged. Fully tap the idyllic scenery, organize the pastoral scenery according to the principles of garden art, highlight different characteristics and styles, to provide leisure, viewing and entertainment for visitors, and let farmers realize the pattern of income without harvest; we should promote the transformation of houses into guest rooms. It is necessary to let farmers start their own businesses, or form a share in the form of "farm joy", let idle houses fully use, excavate the remains of rural dust, wake up the countryside sleeping resources, let idle abandoned resources burst out new vitality; It is necessary to promote the movement of labor change, constantly develop experiential agriculture that conforms to the laws of agricultural production and the demand of tourists for consumption, so that boring agricultural labour becomes a new way for citizens to experience the process of agricultural production.

\subsection{To Promote Leisure Agriculture and Rural Tourism modernization}

It is necessary to promote the diversification of the functions of the industry, according to the idea of supply-side structural reform, to expand the function and meet the demand, and to vigorously develop the diversified modes of farming, fishing, animal husbandry, grassland tourism, forest health and so on; It is necessary to promote the agglomeration of industrial development, adapting measures to local conditions, scientifically plan, optimize the layout, define the direction of development, build industrial characteristics, create leisure agricultural industrial belts and industrial clusters, promote diversification of the main business bodies, and adhere to the principle of taking agriculture as the basis. Under the principle of farmers' main body, we should encourage industrial and commercial enterprises and other social entities to participate in the development, guide more modern elements to leisure agriculture and rural tourism, and promote faster and better development. To give full play to the leading role of financial funds, to leverage financial funds, to drive social funds, and to enable people to invest in basic public and supporting service facilities so that they can be well managed and commonly used; it is necessary to promote the standardization of business services, strengthen guidance, norms, and education and training, to promote the 
standardization of leisure agriculture and rural tourism management and service standardization, to promote the upgrading of industries, and to promote the overall upgrading of agriculture, the overall progress of rural areas, the all-round development of farmers, the strengthening of agriculture and the beauty of rural areas. The peasants have become rich and contributed to their strength.

\section{Conclusion}

In a word, with the support of a series of industrial policies and measures, talents, funds, management, information and other factors accelerate the return to rural areas, to invest in leisure agriculture and rural tourism, actively expand the multi-function of agriculture and innovation the types of trade, and improve the function of experience. To optimize the industrial layout, the supply structure of leisure agriculture and rural tourism in China is more optimized, the essential resources are more active, the main body is diversified, the forms of business are diversified, and the modern facilities, To promote the development of leisure agriculture and rural tourism agglomeration and service standardization, to promote the realization of rural revitalization strategy.

\section{References}

[1] Yang Yutiing, He Jianjia, Liu Jisheng. Research on the Path Evolution of Rural Tourism Resources Development under the Background of "Rural Revitalization Strategy"-based on the Perspective of Evolutionary Game [J]. Enterprise Economy, 2018 (1): 24-30.

[2] Zou Wenchuan, Zhang Shulin. Research on the Integrative Development Model of Science and Technology Agriculture and Rural Tourism under the Strategic Background of Rural Revitalization: A Case Study of Linfengzhen, Changshou District, Chongqing [J]. Rural Science and Technology, 2018 (9): 12-13

[3] Chang Jie, He Peng, Gao Wenbo, et al. Study on Spatial pattern of Leisure Agriculture in Chengdu [J]. Agricultural Resources and Regionalization in China, 2018 (4): 206-214

[4] Wu Qing, Li Xiangui, Zhang Ming. Study on Spatial Pattern and influencing factors of Leisure Agriculture Demonstration Sites in Hubei Province [J]. Regional Research and Development, 2017, 36 (1): 158-163.

[5] Xu Xiantang, Liu Dajun, Hu Jing, et al. Spatial Distribution Characteristics and Influencing Factors of National Rural Tourism sites: A Case Study of National Leisure Agriculture and Rural Tourism Demonstration Sites [J]. Economic Geography, 2015, 35 (9): 182-188. 